\title{
SERTIFIKASI HALAL DAN SERTIFIKASI NON HALAL PADA PRODUK PANGAN INDUSTRI
}

\author{
Asep Syarifuddin Hidayat \& Mustolih Siradj \\ Asosiasi Pengacara Syariah Indonesia (DPN APSI) \\ Jln. RM. Harsono No.06, Ragunan - Pasar Minggu, Jakarta Selatan, Indonesia \\ E-mail: asepsyarif@hotmail.com; mustolihsiradj@yahoo.co.id
}

\begin{abstract}
Non Halal Certification and Halal Certification in Food Products Industry. As a commodity, food has a very large role in improving national food image in the international community and foreign exchange at the same time. However, food safety must be considered seriously. The enactment of Act Halal Product Guarantee (UUJPH) aims to provide comfort, security, safety, and the certainty of availability of halal products for people to consume and use the products; moreover, people get peace in consuming and using those goods. Certification and labelling on food products are a measurement and controlling, so it avoids consumers' determination and dangers.
\end{abstract}

Keywords: halal certification, food product industry, consumer, the act halal product guarantee

\begin{abstract}
Abstrak. Sertifikasi Halal dan Sertifikasi Non Halal pada Produk Pangan Industri. Sebagai komoditas dagang, pangan memiliki peranan yang sangat besar dalam peningkatan citra pangan nasional di dunia internasional dan sekaligus penghasil devisa. Pada saat yang sama keamanan pangan harus mendapatkan perhatian serius. Lahirnya Undang-Undang Jaminan Produk Halal (UUJPH) bertujuan memberikan kenyamanan, keamanan, keselamatan, dan kepastian ketersediaan produk halal bagi masyarakat dalam mengonsumsi dan menggunakan produk sehingga masyarakatkan mendapatkan ketenangan batin dalam mengkonsumsi dan menggunakan barang. Sertifkasi dan label pada produk pangan menjadi alat ukur dan kontrol agar tidak merugikan dan membahayakan konsumen.
\end{abstract}

Kata kunci: sertifikat halal, produk pangan industri, konsumen, UU jaminan produk halal

\section{Pendahuluan}

Pangan $^{1}$ merupakan kebutuhan dasar manusia yang paling utama dan pemenuhannya merupakan bagian dari hak asasi setiap rakyat di Indonesia. Pangan harus senantiasa tersedia secara cukup, aman, bermutu, bergizi, dan beragam dengan harga yang terjangkau oleh daya beli masyarakat, serta tidak bertentangan dengan agama, keyakinan, dan budaya masyarakat. Untuk mencapai semua itu, perlu diselenggarakan suatu sistem pangan yang memberikan pelindungan, baik bagi pihak yang memproduksi maupun yang mengonsumsi. Pemanfaatan pangan atau konsumsi pangan akan menghasilkan sumber daya manusia yang

Naskah diterima: 28 Januari 2015, direvisi: 27 Februari 2015, disetujui untuk terbit: 04 Maret 2015.

${ }^{1}$ Pengertian pangan merujuk pada Pasal 1 ayat (1) UU No. 18 Tahun 2012 tentang Pangan mencakup definisi yang sangat luas, yakni segala sesuatu yang berasal dari sumber hayati produk pertanian, perkebunan, kehutanan, perikanan, peternakan, perairan, dan air, baik yang diolah maupun tidak diolah yang diperuntukan sebagai makanan atau minuman bagi konsumsi manusia, termasuk bahan tambahan pangan, bahan baku pangan, dan bahan lainnya yang digunakan dalam proses penyiapan, pengolahan, dan/atau pembuatan makanan atau minuman. berkualitas dan unggul sebagai salah satu faktor penentu keberhasilan pembangunan. Hal itu dilakukan melalui pemenuhan asupan pangan yang beragam, bergizi seimbang, serta pemenuhan persyaratan keamanan, mutu, dan gizi pangan.

Pelaku usaha pangan bertanggung jawab terhadap pangan yang diedarkan, terutama apabila pangan yang diproduksi menyebabkan kerugian, baik terhadap gangguan kesehatan maupun kematian orang yang mengonsumsinya. ${ }^{2}$ Masyarakat juga perlu mendapatkan informasi yang jelas mengenai setiap produk pangan yang dikemas sebelum membeli dan mengonsumsi pangan. Informasi tersebut terkait dengan asal, keamanan, mutu, kandungan gizi, dan keterangan lain yang diperlukan. Oleh karena itu, perlu ditetapkan ketentuan mengenai label dan iklan pangan sehingga masyarakat dapat mengambil keputusan ber-

\footnotetext{
${ }^{2}$ Pasal 3 (e) UU No. 8 Tahun 1999 tentang Perlindungan Konsumen menyatakan: "Perlindungan konsumen bertujuan ....menumbuhkan kesadaran pelaku usaha mengenai pentingnya perlindungan konsumen sehingga tumbuh sikap yang jujur dan bertanggung jawab dalam berusaha”.
} 
dasarkan informasi yang benar dan akurat. Akses informasi adalah bagian terpenting dalam memenuhi prinsip keterbukaan informasi bagi konsumen yang di dalamnya mengandung makna adanya kepastian hukum sebagaimana tujuan yang digariskan dalam penyelenggaraan perlindungan konsumen. ${ }^{3}$

Oleh sebab itu, akurasi dan kebenaran informasi bagi konsumen begitu urgen untuk menghindarkannya konsumen dari ekses negatif ${ }^{4}$ mengingat saat ini kemajuan ilmu pengetahuan dan teknologi di bidang pangan berkembang demikian sangat pesat. Pengolahan produk pangan dengan memanfaatkan kemajuan ilmu pengetahuan dan teknologi memungkinkan percampuran antara yang halal dan yang haram, baik disengaja maupun tidak. Untuk mengetahui kehalalan dan kesucian suatu pangan, diperlukan suatu kajian khusus yang membutuhkan pengetahuan multidisiplin, seperti pengetahuan di bidang pangan, kimia, biokimia, teknik industri, biologi, farmasi, dan pemahaman tentang syariat. Realitanya banyak produk yang beredar di masyarakat belum semua terjamin kehalalannya meskipun pelaku usaha ${ }^{5}$ menyatakan produk yang dipasarkan dinyatakan halal.

Dengan IPTEK semua yang diinginkan dapat disediakan, diperlukan pelbagai zat tambahan dalam memproses pangan. Zat tambahan ini dapat dibuat secara kimiawi, atau secara bioteknologi serta dapat juga diekstraksi dari tanaman atau hewan. Di sinilah kemungkinan terjadinya perubahan makanan dari halal menjadi tidak halal, yaitu jika bahan tambahan berasal dari ekstraksi hewan tidak halal. ${ }^{6}$ Pengaruh IPTEK ini juga dapat melanda makanan tradisional. Kue atau jajanan yang biasa disajikan di sekitar rumah untuk suguhan (kudapan) misalnya, meskipun jenis dan namanya sama bisa jadi tidak sama dengan kue yang diperoleh di pasar swalayan atau pasar modern karena telah diberi pemanis buatan, pewarna yang tidak alami atau bahan penolong rasa lainnya yang disesuaikan dengan permintaan, tren minat dan gaya hidup konsumen.

${ }^{3}$ Pasal 3 huruf d Undang-Undang No. 8 Tahun 1999 tentang Perlindungan Konsumen (UUPK)

${ }^{4}$ Lihat Pasal 3 (b) Undang-Undang No. 8 Tahun 1999 tentang Perlindungan Konsumen.

${ }^{5}$ Literatur ekonomi lebih sering menggunakan sebutan pengusaha, sedangkan dalam konteks hukum perlindungan konsumen cenderung menggunakan kata Produsen atau Pelaku Usaha. Lihat Ahmad Miru, Prinsip-Prinsip Perlindungan Hukum Bagi Konsumen Indonesia, (Jakarta: PT Rajawali Press), h. 33.

${ }^{6}$ Wiku Adisasmito, "Analisis Kebijakan Nasional MUI dan BPOM dalam Labeling Obat dan Makanan”, Makalah Fakultas Kesehatan Masyarakat Universitas Indonesia, 2008, h. 3.
Indonesia sebagai negara berpenduduk muslim terbesar di dunia yang ( $85 \%$ dari 250 juta jiwa) tentu saja berkepentingan dengan peredaran produk yang aman dan berstandar halal. Sebab secara otomatis kaum muslim menjadi konsumen terbesar (mayoritas) di negeri ini di samping menjadi incaran dan target impor negara-negara lain. Maka itu sepatutnya konsumen dalam negeri mendapatkan perlindungan dalam memperoleh kepastian tentang kehalalan produk pangan yang beredar. ${ }^{7}$ Sebagai ilustrasi, pada 2013 kita mengimpor dari Thailand dan langganan impor daging sapi baik yang berasal dari Selandia Baru atau Australia. Selain itu pasokan makanan olahan seperti cokelat, yogurt, makanan ringan (snack) dan lain-lain yang pemasoknya masih didominasi oleh Nestle, Unilever, Carrefour, dan sebagainya. ${ }^{8}$

Kedudukan konsumen terhadap pelaku usaha pada umumnya memang sangat lemah. Konsumen menjadi objek dari aktivitas bisnis dari pelaku usaha melalui kiat promosi, iklan dan cara penjualan serta penerapan perjanjian-perjanjian standar yang acapkali secara sengaja merugikan konsumen. Lemahnya posisi konsumen diakui secara internasional sebagaimana tercermin dalam Resolusi Majelis Umum PBB N.A/ RES/39/248 Tahun 1985 tentang Guidlines for Consumer Protection. ${ }^{9}$ Resolusi tersebut menghendaki agar konsumen di manapun berada dari segala bangsa mempunyai hak-hak dasar tertentu terlepas dari status sosialnya dijamin hak-hak dasarnya yakni hak untuk mendapatkan informasi yang jelas, jujur, dan benar, hak untuk mendapatkan keamanan dan keselamatan, hak untuk memilih, hak untuk didengar, dan hak untuk mendapatkan ganti rugi. Maka itu, Persatuan BangsaBangsa (United Nation) mengimbau anggotanya untuk memberlakukan hak-hak tersebut di negara masingmasing. ${ }^{10}$

Masalah produk berstandar halal seharusnya sudah menjadi bagian integral yang tak terpisahkan dari praktik perdagangan dan ekonomi global yang menuntut adanya standar-standar dan kualitas baku

${ }^{7}$ Pasal 8 ayat 1 butir h UU Perlindungan Konsumen menyatakan pelaku usaha dilarang memproduksi, dan/atau memperdagangkan barang dan/atau jasa yang tidak mengikuti ketentuan berproduksi secara halal sebagaimana pernyataan halal yang dicantumkan dalam label.

${ }^{8}$ Sapta Nirwanda, Ikhtiar Menjadi Produsen Halal Lifestyle, dalam GATRA, 19 Juli 2015.

${ }^{9}$ Susanti Adi Nugroho, Proses Penyelesaian Konsumen Ditinjau dari Hukum Acara Serta Kendala Implementasinya, (Jakarta: PT Prenada Media Gorup, 2011), h. 2.

${ }^{10}$ Susanti Adi Nugroho, Proses Penyelesaian Konsumen Ditinjau dari Hukum Acara Serta Kendala Implementasinya, h. 3. 
internasional untuk mendapatkan kepercayaan dari konsumen lintas negara. Dengan begitu aliran barang, jasa, modal, ilmu pengetahuan antar negara menjadi makin mudah. ${ }^{11}$ Perdagangan internasional berpengaruh besar terhadap perekonomian antar negara tersebut yang dapat menciptakan iklim kondusif yang saling menguntungkan dari perdagangan timbal balik, bahkan lebih efesien dalam memproduksi dan memasarkan barang. ${ }^{12}$ Banyak pakar yang menyimpulkan bahwa manfaat perdagangan lintas negara melampaui manfaat persaingan militer dan perluasan wilayah. ${ }^{13}$

Mengonsumsi pangan yang halal adalah hak dasar setiap muslim. Hal ini bukan saja terkait dengan keyakinan beragama, namun ada dimensi kesehatan, ekonomi dan keamanan. Maka dengan penduduk yang mayoritas muslim, tanpa diminta sudah semestinya negara hadir melindungi warganya dalam pemenuhan hak-hak mendasar warganya. Selaras dengan itu pelaku usaha (produsen) juga sudah seharusnya memberikan perlindungan kepada konsumen. Untuk kepentingan tersebut, maka dituntut peran yang lebih aktif negara dalam pengaturan sistem ekonomi yang dijabarkan dalam strategi yang dilakukan pemerintah/negara dalam menjalankan instrumen perdagangan/bisnis di antaranya melalui regulasi. ${ }^{14}$

Gaya hidup halal (halal lifestyle) belakangan ini memang tengah melanda dunia, tidak hanya menggejala pada negara-negara yang mayoritas berpenduduk muslim tetapi juga di negara berpenduduk mayoritas non muslim. Kesadaran pemenuhan pangan halal meningkat di kancah global beriringan dengan menggeliatnya wisata halal global yang tidak melulu terbatas pada sektor destinasi wisata yang berkait situs keislaman (religi) tetapi menyangkut pemenuhan kebutuhan-kebutuhan wisata itu sendiri. Perusahaan berskala global (multinational corporation) saat ini telah menerapkan sistem halal, sebut saja seperti Japan Airlaines, Singapore AirLines, Qantas, Chatay Pacific (Hong Kong), America Airlines menyediakan menu halal (moslem meal). Gejala ini juga merambah negara Amerika, Australia, Jepang, Cina, India, dan

\footnotetext{
${ }^{11}$ Violetta Sumatupang, Hukum Kepariwisataan Berbasis Ekspresi Budaya Tradisional, (Bandung: Alumni, 2015), h. 155.

${ }^{12}$ Hatta, Perdagangan Internasional dalam Sistem GATT dan WTO, Aspek-Aspek Hukum dan Non Hukum, (Bandung: PT Refika Aditama, 2006), h.17.

${ }^{13}$ Hatta, Perdagangan Internasional dalam Sistem GATT dan WTO, Aspek-Aspek Hukum dan Non Hukum, h.1.

${ }^{14}$ Ali Yafie Dkk, Fikih Perdagangan Bebas, (Jakarta: Teraju, 2004), h. 77.
}

negara-negara Amerika Latin. ${ }^{15}$ Khusus Jepang, negara ini memiliki perhatian sangat serius terhadap pengembangan tren halal, salah satu indikasinya dengan digelarnya Japan Halal Expo yang selalu ramai sehingga cukup berhasil menyedot perhatian dan minat pelbagai pihak. Japan Halal Expo adalah pameran berskala besar yang memuat produk halal buatan Jepang. Tercatat, saat ini sudah ada 350 restoran di Jepang yang telah menyediakan makanan halal, 54 di antaranya adalah restoran khusus makanan negara tersebut. ${ }^{16}$

Data dari State of The Global Islamic Economy 2014$2015^{17}$ menyebutkan indikator tren bisnis halal terlihat pada lima bidang industri terus menunjukkan kemajuan. Antara lain jasa keuangan islami (Islamic finance), makanan halal, busana muslim, media dan rekreasi halal, serta farmasi dan kosmetik halal. Sayangnya, Indonesia menempati urutan kesepuluh dari negara-negara pelaksana ekonomi Islam itu. Kesepuluh besar negara tersebut adalah Malaysia, Uni Emirat Arab, Bahrain, Oman, Arab Saudi, Qatar, Kuwait, Yordania, Pakistan dan Indonesia. Kondisi ini menandakan bahwa industri halal di Indonesia masih tertinggal dibandingkan dengan beberapa negara tetangga, bahkan dengan negara-negara non muslim. Padahal potensinya begitu besar. Peringkat tertinggi untuk negara produsen makanan halal dikuasai oleh Malaysia, Brasil, Uni Emirat Arab dan Amerika Serikat. ${ }^{18}$

Menyediakan pangan halal dan aman adalah bisnis yang sangat prospektif, karena dengan label (sertifikasi) halal dapat mengundang pelanggan loyal yang bukan saja diminati oleh muslim tetapi juga masyarakat non muslim. Sebaliknya bagi produsen yang tidak memberikan keterangan halal yang memasarkan produknya di negara seperti Indonesia yang berpenduduk mayoritas muslim, produknya kurang diminati sehingga merugikan pelaku usaha sendiri. ${ }^{19}$ Pangan halal bagi muslim itu terbukti berkualitas dan sangat baik untuk kesehatan tubuh manusia. Seperti daging yang berasal dari hewan yang halal yang disembelih sesuai

${ }^{15}$ Asrorun Ni'am Sholeh, "Halal Jadi Tren Global", dalam GATRA, 29 Juli 2015.

16 "Japan Halal Expo 2015", dalam Jurnal Halal No. 113/Mei-Juni Th.XVIII 2015, (Mei-Juni 2015), h.18.

17 "Produk Halal di Negera Muslim Terbesar", dalam Metrotvnews. com, sebagaimana dalam http://telusur.metrotvnews.com/ $\mathrm{read} / 2015 / 07 / 24 / 415252 /$ produk-halal-di-negara-muslim-terbesar, diunduh pada 9 September 2015.

18 "Produk Halal di Negera Muslim Terbesar", dalam Metrotvnews. com, diunduh 9 September 2015.

${ }^{19}$ Ahmad Miru, Prinsip-prinsip Perlindungan bagi Konsumen di Indonesia, (Jakarta: PT Rajagrafindo Persada, 2011), h. 192. 
dengan ketentuan Islam ternyata lebih sehat untuk dikonsumsi. ${ }^{20}$ Adanya sertifikasi-labelisasi halal bukan saja bertujuan memberi ketentraman batin pada umat Islam tetapi juga ketenangan berproduksi bagi pelaku usaha. Apalagi dalam konteks globalisasi ekonomi dan pasar global, sertifikasi-labelisasi halal pangan makin diperlukan. ${ }^{21}$

\section{Pandangan Islam Terhadap Pangan Halal}

Dalam pandangan Islam persoalan memilih untuk mengonsumsi yang halal haram merupakan persoalan yang sangat penting, bahkan dianggap sebagai inti keberagamaan, karena setiap orang yang akan menggunakan atau melakukan, mengonsumsi sangat dituntut oleh agama untuk memastikan terlebih dahulu kehalalan dan keharamannya. Jika halal, ia boleh melakukan, menggunakan atau mengonsumsinya. Namun jika jelas keharamannya maka harus dijauhkan dari seorang muslim. Sedemikian menentukan kedudukan halal dan haram hingga sebagai ulama menyatakan "Hukum Islam (fikih) adalah pengetahaun tentang halal dan haram". Hal tersebut secara jelas dinyatakan dalam Q.s. al-Baqarah [2]: 168. Kandungan makna ayat tersebut memerintahkan seluruh umat manusia agar mengonsumsi makanan yang halal. Apalagi bagi orangorang yang beriman, tentu lebih utama dan bagi wajib untuk mengamalkan tuntutan qurani serta mematuhi tuntutan Allah tersebut.

Lebih jauh, makanan dalam pandangan Islam adalah menyangkut hajat umat manusia secara keseluruhan, bukan hanya muslim. Demikian pula soal makanan yang halal dan haram adalah urusan luas masyarakat pada umumnya. Makanan yang dikonsumsi secara biologis akan diproses, di antaranya menjadi saripati kehidupan berupa sel sperma atau sel telur, yang berikutnya tumbuh dan menjelma menjadi janin anak manusia sebagai generasi pelanjut orang tua dan umat manusia pada umumnya. Maka bicara tentang makanan, halal-haram, berarti bicara

\footnotetext{
${ }^{20}$ Ahmad Miru, Prinsip-prinsip Perlindungan bagi Konsumen di Indonesia, h.192.

21 Sejak lama Malaysia dan Singapura menguasai penyediaan Pelabuhan Halal dikuasai oleh Malaysia dan Singapura. Semua barang atau produk yang dikirim ke negara Timur Tengah atau ke Indonesia selalu melewati pelabuhan dua negara tersebut. Di pelabuhan tersebut semua produk peti kemas dan dikelola dengan cara halal, jika tidak halal maka negara-negara yang menuntut adanya sertifikasi halal tidak mau menerima produk tersebut. Indonesia baru akan menggagas pelabuhan halal melalui IPC Logistic Services yang merupakan anak perusahaan dari PT Pelabuhan Indonesia II (Pelindo II) karena potensi pelabuhan halal cukup menjanjikan (Koran Kompas, Senin 26 Oktober 2015, h. 17).
}

tetang keturunan dan generasi pelanjut yang akan menentukan masa depan peradaban umat manusia dengan karakteristik halal-haram tersebut. ${ }^{22}$

Halal adalah sesuatu yang jika digunakan tidak mengakibatkan mendapatkan siksa (dosa). Sedangkan haram adalah sesuatu yang oleh Allah Swt. dilarang dilakukan dengan larangan tegas di mana orang yang melanggarnya diancam siksa oleh Allah di akhirat. ${ }^{23}$ Pangan halal ${ }^{24}$ adalah pangan yang jika dikonsumsi tidak mengakibatkan mendapat siksa (dosa), dan pangan haram adalah pangan yang jika dikonsumsi akan berakibat mendapat dosa dan siksa azab dari Allah Swt. ${ }^{25}$ Selain itu, menurut Nabi Muhammad Saw. mengonsumsi yang haram menyebabkan dosa yang dipanjatkan tidak akan dikabulkan dan segala amal ibadah yang dilakukan tidak akan diterima oleh Allah. Atas dasar itu, bagi umat Islam, sejalan dengan ajaran Islam, menghendaki agar produkproduk yang akan dikonsumsi dijamin kehalalan dan kesuciannya. Menurut Islam mengonsumsi yang halal, suci dan baik (thayyib) merupakan perintah agama dan hukumnya adalah wajib. Cukup banyak ayat dan hadis yang menyatakan hal tersebut di antaranya al-Baqarah [2]: 29, 195, al-Jâtsiyah [45]: 13, al-A'râf [7]: 157, al-Mâ-idah [5]: 3, al-An'âm [6]: 145, al-Nahl [16]: 115.

Menurut hukum Islam ada bahan-bahan yang sudah jelas kehalalannya oleh dalil ketentuannya sudah jelas atau disebut qathî̀ tsubût (Alquran atau Hadis Mutawatir) yang mencakup jenis-jenis pangan yang dibolehkan untuk dikonsumsi oleh dalil yang bersifat umum sepanjang tidak ada dalil yang mengharamkannya dan ada pula jenis pangan atau bahan makanan yang sudah jelas keharamannya oleh dalil qathî al-dilâlah. Di antara yang halal dan haram itu terdapat cukup banyak pangan yang masih samar-samar (syubhat) status hukumnya yang tidak masuk dalam kategori pertama dan kedua (mukhtalaf

${ }^{22}$ Sulhan Abu Fitra, "Makanan Menentukan Kualitas Generasi dan Peradaban”, dalam Jurnal Halal No. 113/Mei-Juni Th.XVIII 2015, (Mei-Juni 2015), h. 30-31.

${ }^{23}$ Ma'ruf Amin, Fatwa dalam Sistem Hukum Islam, (Jakarta: Elsas, 2011), h. 43.

${ }^{24}$ Definisi pangan halal mengacu pada Peraturan Pemerintah No. 69 Tahun 1999 tentang Label dan Iklan Pangan dinyatakan sebagai pangan yang tidak mengandung unsur atau bahan yang haram atau dilarang untuk dikonsumsi umat Islam, baik yang menyangkut bahan baku pangan, bahan tambahan pangan, bahan bantu dan bahan penolong lainnya termasuk bahan pangan yang diolah melalui proses rekayasa genetika dan iradiasi pangan, dan yang pengelolaannya dilakukan sesuai dengan ketentuan hukum agama Islam.

${ }^{25}$ Mảruf Amin, Fatwa dalam Sistem Hukum Islam, h. 43. 
fîh). ${ }^{26}$ Produk-produk olahan, baik makanan, minuman, obat-obatan maupun kosmetik kiranya dapat dikategorikan sebagai musytabihât (syubhat), apalagi produk-produk tersebut berasal dari negara yang berpenduduk mayoritas non muslim, sekalipun bahan baku halal tetapi proses penyimpanan atau pengolahannya bisa saja tercampur atau menggunakan bahan-bahan haram. ${ }^{27}$

Secara garis besar, jenis pangan atau bahan pangan terdiri atas hewani dan non hewani. Semua kelompok non hewani, seperti nabati dan benda cair menurut syariat Islam halal dimakan kecuali yang najis (atau yang tekena najis), berbahaya, dan yang memabukkan. ${ }^{28}$ Demikian juga yang lain, pada dasarnya hukumnya adalah halal kecuali ada dalil yang mengharamkannya sebagaimana dinyatakan dalam Q.s. al-Baqarah [2]: 29, al-A'râf [7]: 32, al-Jâtsiyah [45]: 13. Selain itu, ada kaidah fikih yang menyatakan: (al-ashl fi al-asy-yâ

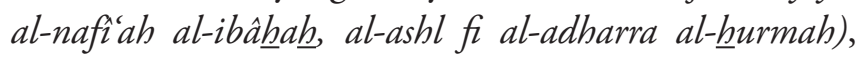
hukum asal sesuatu yang bermanfaat itu adalah boleh dan hukum asal sesuatu yang berbahaya adalah haram. Mengenai ke-haram-an benda najis atau terkena najis disebutkan dalam Q.s. al-A'râf [7]: 157. Yang dimaksud dengan buruk (khabâ-its) dalam ayat tersebut menurut ulama adalah najis.

\section{Peran MUI dan BPOM dalam Sertifikasi dan Labeling Produk Pangan}

Sebagai ikhtiar dan implementasi atas langkah strategis melindungi umat dari serbuan pelbagai peredaran produk pangan yang mengandung bahanbahan non halal Majelis Ulama Indonesia (MUI) mendirikan Lembaga Pengkajian Pangan, Obat-obatan dan Kosmetika (LPPOM) melalui SK No. 018/ MUI/I/1989 tertanggal 6 Januari 1989/26 Jumadil Awal $1409 \mathrm{H}$, lembaga ini beranggotakan unsur ulama dan ilmuwan yang berkompeten dan sejumlah ahli bidang pangan, kimia, biokimia, fikih Islam dan lainlain. LPPOM MUI semula dimaksudkan sebagai respon atas peredaran bahan pangan tertentu yang berasal dari babi. Isu "lemak babi" ini menyulut gelombang protes yang cukup besar dari kalangan umat Islam. Di sisi produsen, berdampak omzet penjualan produk bersangkutan kontan anjlok drastis. ${ }^{29}$ Maka LPPOM-

\footnotetext{
${ }^{26}$ Ma'ruf Amin, Fatwa dalam Sistem Hukum Islam, h. 321.

${ }^{27}$ Ma'ruf Amin, Fatwa dalam Sistem Hukum Islam, h. 40.

${ }^{28}$ Ma'ruf Amin, Fatwa dalam Sistem Hukum Islam, h. 21.

29 "Refleksi 17 Tahun LPPOM MUI", dalam http://www. antaranews.com/berita/26972/refleksi-17-tahun-lppom-mui, diunduh pada 8 September 2015.
}

MUI didirikan agar dapat memberikan rasa tentram dan ketenangan batin pada umat tentang produk yang dikonsumsinya. ${ }^{30}$

Tahun 1994 LPPOM MUI mengawali kiprah menggagas sertifikasi halal terhadap pangan yang beredar di pasaran mulai dilakukan. Proses sertifikasi dilakukan sendiri oleh MUI. Sementara izin label halal pada kemasan pangan diberikan oleh Departemen Kesehatan (Depkes) c.q. Badan Pengawasan Obat dan Makanan (BPOM). Model semacam ini menyebabkan terjadinya dualisme dalam pengurusan sertifikat dan label halal. Sehingga produk yang sudah mendapatkan sertifikat halal dari MUI masih harus diperiksa lagi oleh BPOM guna mendapatkan izin penggunaan logo halal. Untuk memangkas prosedur birokrasi, 21 Juni 1996 melalui piagam kerja sama antara Departemen Kesehatan, Departemen Agama dan Majelis Ulama Indonesia akhirnya disepakati bahwa pencantuman label halal pada produk pangan akan ditangani bersama oleh tiga instansi tersebut. ${ }^{31}$ Dalam pelaksanaannya sertifikat halal dikeluarkan oleh MUI berdasarkan audit tim gabungan tiga instansi tersebut. Dengan sertifikat halal MUI tersebut perusahaan bisa langsung mendapatkan izin pencantuman label halal dari BPOM (Badan Pengawasan Obat dan Makanan). Sehingga tidak ada lagi dualisme dalam kepengurusan halal. BPOM telah menyerahkan sepenuhnya sertifikasi halal ini kepada Komisi Fatwa MUI. Pemberian atau penolakan sertifikat halal sepenuhnya berada di MUI. Berdasarkan fatwa MUI ini, BPOM akan memberi persetujuan pencantuman label halal bagi yang memperoleh sertifikat halal, atau memberi penolakan bagi yang tidak mengantongi sertifikat halal. Hal ini, memberikan kepastian bagi konsumen dalam mengonsumsi produk makanan. $^{32}$

Dalam perjalanannya, LPPOM MUI telah melakukan sertifikasi terhadap pelbagai produsen pangan, obat dan kosmetik, baik di dalam maupun di luar negeri. Guna menjangkau produsen di tingkat daerah LPPOM MUI telah mengembangkan sayapnya melalui pendirian dan pemberdayaan LPPOM MUI Daerah di pelbagai wilayah. ${ }^{33}$ LPPOM MUI daerah mengeluarkan

\footnotetext{
30 Lembaga Pengkajian Pangan Obat-Obatan dan Kosmetik (LPPOM MUI), Indonesia Halal Directory 2013-2014, h. 9.

31 Lembaga Pengkajian Pangan Obat-Obatan dan Kosmetik (LPPOM MUI), Indonesia Halal Directory 2013-2014, h. 9.

32 Wiku Adisasmito, "Analisis Kebijakan Nasional MUI dan BPOM dalam Labeling Obat dan Makanan", Makalah Fakultas Kesehatan Masyarakat Universitas Indonesia, 2008, h. 5.

33 Wiku Adisasmito, "Analisis Kebijakan Nasional MUI dan BPOM", h. 5.
} 
sertifikat halal untuk produk pangan lokal di daerahnya, ${ }^{34}$ seperti pemotongan hewan, produk usaha kecil dan menengah serta produk daerah lainnya.

Pada level global, LPPOM MUI aktif menjalin kerja sama dengan lembaga sertifikasi halal internasional. LPPOM MUI memprakarsai World Halal Food Council (WHFC) atau Dewan Halal Pangan Dunia. Kongres WHFC 2004 memantapkan langkah-langkah dengan keluarnya kesepakatan antar lembaga sertifikasi halal untuk membuat standar pemeriksaan halal yang sama untuk seluruh negara anggota Dewan Halal Dunia. Standar halal MUI dan auditor halal LPPOM MUI telah menjadi pedoman di Indonesia dan menjadi rujukan pada 43 lembaga sertifikasi halal luar negeri di 23 negara. ${ }^{35}$

Kedudukan LPPOM MUI sebagai pemeriksa dan pemberi sertifikat halal makin kokoh dan mendapatkan legitimasi yuridis dari negara dengan terbitnya Keputusan Menteri Agama (KMA) Nomor 519 Tahun 2001 Tentang Lembaga Pelaksana Pemeriksaan Pangan Halal yang menunjuk Majelis Ulama Indonesia (MUI) sebagai lembaga pelaksana pemeriksaan pangan yang dinyatakan halal, yang dikemas untuk diperdagangkan di Indonesia. ${ }^{36}$ Pelaksanaan kegiatan pemeriksaan pangan tersebut meliputi enam hal penting yaitu ${ }^{37}$ pemeriksaan dan/atau verifikasi data pemohon, pemeriksaan proses produksi, pemeriksaan laboratorium, pemeriksaan pengepakan, pengemasan dan penyimpanan produk, pemeriksaan sistem transportasi, distribusi, pemasaran dan penyajian, pemrosesan dan penetapan Sertifikasi Halal.

Dengan terbitnya KMA Nomor 519/2001 tersebut mengukuhkan LPPOM MUI menjadi satu-satunya lembaga yang menjadi rujukan dan memiliki otoritas dalam pemeriksaan dan pemberian sertifikasi halal di Indonesia. Keputusan tersebut berlaku sejak 31 November 2001 sampai sekarang. Sertifikat produk halal menjadi syarat untuk mencantum label halal. Ini artinya sebelum pelaku memperoleh izin untuk mencantumkan label halal atas produk pangan, terlebih dahulu mesti mengantongi sertifikat produk halal

34 Saat ini LPPOM MUI sudah hadir di 33 provinsi. Lihat, Lembaga Pengkajian Pangan Obat-Obatan dan Kosmetik (LPPOM MUI), Indonesia Halal Directory 2013-2014, h.56-57.

${ }^{35}$ Lukmanul Hakim, Bahan Seminar Nasional Halal dan Focus Group Discution di Universitas Djuanda Bogor, 15 Desember 2014, h. 2 .

${ }^{36}$ Pasal 1 Nomor 519 Tahun 2001 Tentang Lembaga Pelaksana Pemeriksaan Pangan Halal

${ }^{37}$ Pasal 2 Nomor 519 Tahun 2001 Tentang Lembaga Pelaksana Pemeriksaan Pangan Halal yang diperoleh LPPOM MUI. Menyangkut beban biaya, ${ }^{38}$ pelaksanaan kegiatan pelaksanaan pemeriksaan pangan dibebankan kepada produsen atau importir yang mengajukan permohonan, anggaran pendapatan dan belanja negara, serta sumber-sumber lain yang sah sesuai peraturan perundang-undangan yang berlaku.

Campur tangan negara dalam penyediaan produk halal tidak hanya di Indonesia, negara tetangga seperti Malaysia dan Thailand juga melakukan hal yang sama. Di Malaysia, untuk mengembangkan industri halal, mereka telah membuat kebijakan memfasilitasi pembentukan Halal Development Corporation (HDC) yang bekerja sama dengan Department of Islamic Development Malaysia (JAKIM) di seluruh wilayah Federal Malaysia. Demikian pula Pemerintah Thailand yang mayoritas penduduknya non Muslim telah memberi perhatian dalam pengembangan industri halal, di mana lembaga The Central Islamic Committee of Thailand (CICOT) bekerja sama dengan Kementerian Agama dan Kementerian Dalam Negeri Thailand berhasil menjadikan Thailand sebagai pusat kuliner dan produk halal di ASEAN. Thailand bahkan juga unggul dalam pengembangan keilmuan serta pengujian indsutri halal dengan konsep Hal-Q yang kini mulai diterima di pasar Internasional. ${ }^{39}$

MUI, dalam melaksanakan proses sertifikasi halal, LPPOM-MUI menggunakan prosedur baku sebagai panduan pelaksanaan, yang kemudian dituangkan dalam bentuk SOP (Standard Operation Procedure). Panduan ini senantiasa dikembangkan dan terus ditingkatkan, sesuai dengan kebutuhan maupun perkembangan ilmu dan teknologi. MUI menetapkan tahapan atau langkah prosedur dan mekanisme penetapan fatwa halal hingga terbitnya sertifikat halal. ${ }^{40}$ Sistem labelisasi yang dilakukan oleh LPPOM MUI dan BP-POM ${ }^{41}$ merupakan kegiatan yang dapat dipertanggungjawabkan. Berdasarkan data dari Badan Pengawas Obat dan Makanan (BPOM), jumlah produk yang beredar di masyarakat sebanyak 194.776. Namun, hanya setengahnya yang telah memiliki sertifikat halal dari Majelis Ulama Indonesia (MUI) dalam masa

\footnotetext{
${ }^{38}$ Pasal 4 Nomor 519 Tahun 2001 Tentang Lembaga Pelaksana Pemeriksaan Pangan Halal

39 "Produk Halal, Jaminan Negara dan Hak Asasi Konsumen", sebagaimana dalam http://www.majalahgontor.net/index.php?option=com_ content\&view=article\&id=429, diunduh pada 8 September 2015

${ }^{40}$ Majelis Ulama Indonesia, "Sistem dan Prosedur Penetapan Fatwa Produk Halal Majelis Ulama Indonesia, "dalam Himpunan Fatwa MUI Sejak 1975, (Jakarta: PT Erlangga, 2015), h. 27-28.

41 Lebih rinci, LPPOM MUI dan BP-POM mengeluarkan peraturan tentang tata cara, panduan dan prosedur mendapatkan sertifikasi halal dan pelabelan.
} 
berlaku tahun 2013-2015. Jumlah produk bersertifikat halal tersebut ada sebanyak 98.543 atau memiliki persentase sebesar 50,6 persen. ${ }^{42}$

Setidaknya, ada delapan jenis informasi ${ }^{43}$ yang bisa diketahui dari label kemasan produk pangan yaitu sertifikasi halal, nama produk, kandungan isi, waktu kedaluwarsa, kuantitas isi, identifikasi asal produk, informasi gizi, dan tanda-tanda kualitas lainnya. Informasi-informasi tersebut mesti diperhatikan dengan seksama supaya konsumen tidak salah beli. Pada setiap kemasan nama produk pada labelnya merupakan informasi utama yang memungkinkan konsumen dapat mengidentifikasi jenis produk itu. Selain keteranganketerangan tersebut, untuk pangan olahan tertentu, pelaku usaha harus mencantumkan keterangan lain yang berhubungan dengan kesehatan manusia pada label. Keterangan dan/atau pernyataan tentang pangan yang dicantumkan dalam label harus benar dan tidak menyesatkan, baik mengenai tulisan, gambar, atau bentuk apapun lainnya.

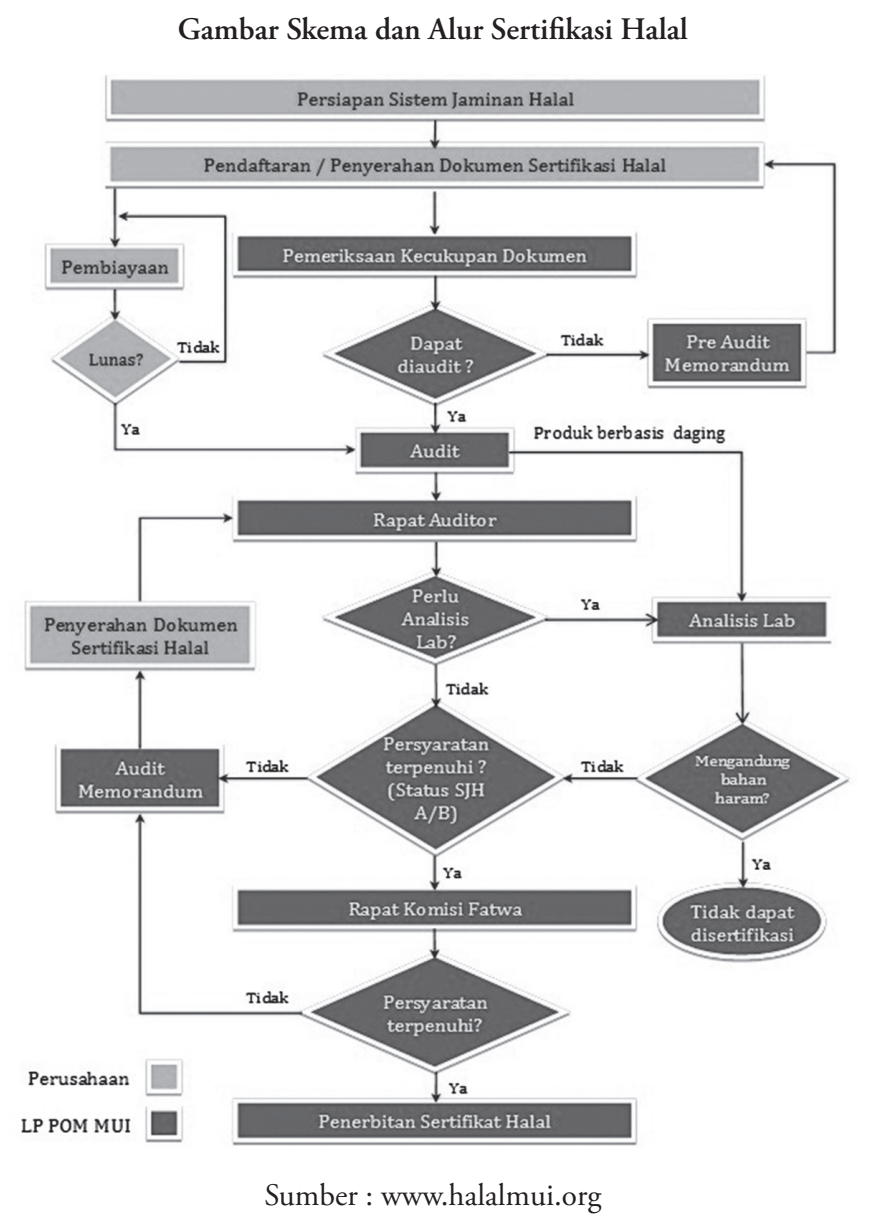

\footnotetext{
${ }^{42}$ Produk Halal di Negara Muslim Terbesar," dalam http://telusur. metrotvnews.com/read/2015/07/24/415252/produk-halal-di-negaramuslim-terbesar, diunduh pada 9 September 2015.

${ }^{43}$ Lihat Pasal 3 ayat (2) Peraturan Pemerintah Nomor 69 Tahun 1999 tentang Label dan Iklan Pangan.
}

Sebagai penanda terhadap produk yang telah dinyatakan halal, LPPOM MUI telah menetapkan logo halal standar terhadap produk yang telah memiliki sertifikat halal sebagaimana dituangkan dalam Surat Keputusan Direktur LPPMU MUI No. SK10/Dir/ LP POM MUI/XII/07 tentang Logo LPPOM MUI. Sayangnya logo standar yang ditetapkan LPPOM MUI pada level implementasi dimaknai berbeda-beda oleh pelaku usaha sehingga di pasaran mudah sekali ditemukan bentuk dan jenis logo halal pada produk pangan yang beredar di pasaran tetapi bentuk, ukuran, dan penempatannya tidak sama. Kenyataan ini tentu saja berpotensi membingungkan konsumen. Hal ini dapat dipahami karena adanya multiinterpretasi bersumber dari kebijakan LPPOM MUI sendiri dengan tidak memberikan acuan dan ketentuan secara ketat dalam memformulasikan syarat dan standar pencantuman logo. Dalam No. SK10/Dir/LP POM MUI/XII/07 tentang Logo LPPOM MUI misalnya tidak ditemukan penjelasan tentang ukuran logo, ukuran dan jarak garis tepi lingkaran dalam dengan garis tepi lingkaran luar, jenis huruf (font), warna logo yang harus dipasang/ditempel, posisi penempatan nomor sertifikat oleh pelaku usaha pada produk yang akan mereka pasarkan. Pengaturan teknis dan rigid ini penting agar pelaku usaha lebih disiplin dan konsumen memperoleh kepastian hukum. ${ }^{44}$

Keterangan gambar : Logo Halal Standar LPPOM MUI

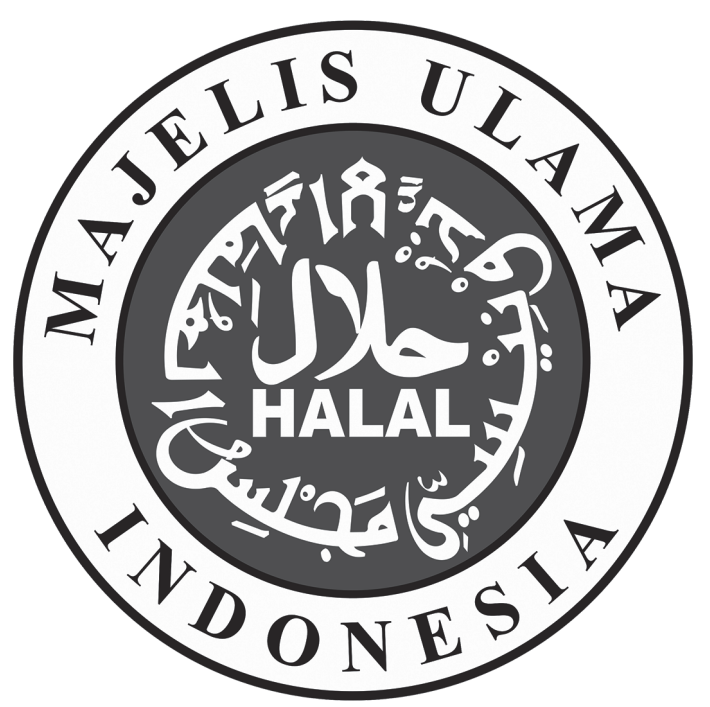

NOMOR SERTIFIKAT HALAL

\footnotetext{
${ }^{44}$ Bandingkan peraturan tentang pencantuman label halal dengan Peraturan Menteri Perdagangan No. 73/M-DAG/PER/9/2015 tentang Kewajiban Pencantuman Label Dalam Bahasa Indonesia Pada Barang
} 


\section{Sertifikasi Halal dalam Undang-Undang Jaminan Produk Halal (UUJPH)}

Doktrin halalan thayyiban (halal dan baik) sangat perlu untuk diinformasikan dan diformulasikan secara efektif dan operasional kepada masyarakat disertai dengan tercukupinya sarana dan prasarana. Salah satu sarana penting untuk mengawal doktrin halâlan thayyiban adalah dengan hadirnya pranata hukum yang mapan, sentral, humanis, progresif, akamodatif dan tidak diskriminatif yakni dengan hadirnya UndangUndang Nomor 33 Tentang Jaminan Produk Halal (UUJPH). ${ }^{45}$

Beberapa faktor yang mendasari pentingnya UUJPH antara lain, pertama $a^{46}$ pelbagai peraturan perundang-undangan yang telah ada yang mengatur atau yang berkaitan dengan produk halal belum memberikan kepastian hukum dan jaminan hukum bagi konsumen untuk dapat mengonsumsi produk halal. Sehingga masyarakat mengalami kesulitan dalam membedakan antara produk yang halal dan haram. Selain itu pengaturan produknya masih sangat terbatas hanya soal pangan belum mencakup obat-obatan, kosmetik, produk kimia biologis dan rekayasa genetik. Kedua, tidak ada kepastian hukum kepada institusi mana keterlibatan negara secara jelas di dalam jaminan produk halal. Sistem yang ada belum secara jelas memberikan kepastian wewenang, tugas dan fungsi dalam kaitan implementasi JPH, termasuk koordinasinya. Ketiga, peredaran dan produk di pasar domestik makin sulit dikontrol akibat meningkatnya teknologi pangan, rekayasa teknologi, bioteknologi dan proses kimia biologis. Keempat, produk halal Indonesia belum memiliki standar dan tanda halal resmi (standar halal nasional) yang ditetapkan oleh pemerintah sebagaimana di Singapura, Amerika Serikat, dan Malaysia. Kelima, sistem informasi produk halal belum sesuai dengan tingkat pengetahuan dan kebutuhan masyarakat tentang produk-produk yang halal. ${ }^{47}$

Undang-Undang Nomor 33 Tahun 2014 tentang Jaminan Produk Halal (UU-JPH) memperkuat dan mengatur pelbagai regulasi halal yang selama ini tersebar di pelbagai peraturan perundang-undangan, di sisi lain UUJPH dapat disebut sebagai payung hukum (umbrella act) bagi pengaturan produk halal. Jaminan Produk Halal (JPH) dalam undang-undang ini men-

${ }^{45}$ Sofyan Hasan, Sertifikasi Halal dalam Hukum Positif, Regulasi dan Implementasinya di Indonesia, (Yogyakarta: Aswaja Pressindo, 2014), h. 351.

${ }^{46}$ Naskah Akademik RUU-JPH, h.6-7.

${ }^{47}$ Naskah Akademik RUU-JPH, h. 3-4. cakup pelbagai aspek tidak hanya obat, makanan dan kosmetik akan tetapi lebih luas dari itu menjangkau produk kimiawi, produk biologi, produk rekayasa genetik, serta barang gunaan yang dipakai, digunakan, atau dimanfaatkan oleh masyarakat. ${ }^{48}$ Pengaturannya pun menjangkau kehalalan produk dari hulu sampai hilir. Proses Produk Halal (PPH) didefinisikan sebagai rangkaian kegiatan untuk menjamin kehalalan produk mencakup penyediaan bahan, pengolahan, penyimpanan, pengemasan, pendistribusian, penjualan, dan penyajian Produk. ${ }^{49}$

Tujuan dari UUJPH adalah untuk menjamin setiap pemeluk agama beribadah dan menjalankan ajaran agamanya, memberikan pelindungan dan jaminan tentang kehalalan Produk yang dikonsumsi dan digunakan masyarakat sesuai dengan asas pelindungan, keadilan, kepastian hukum, akuntabilitas dan transparansi, efektivitas dan efisiensi, serta profesionalitas. Selain itu, penyelenggaraan sistem produk halal bertujuan memberikan kenyamanan, keamanan, keselamatan, dan kepastian ketersediaan Produk Halal bagi masyarakat dalam mengonsumsi dan menggunakan Produk, serta meningkatkan nilai tambah bagi Pelaku Usaha untuk memproduksi dan menjual Produk Halal. ${ }^{50}$

Jaminan produk halal secara teknis kemudian dijabatkan melalui proses sertifikasi. Sebelumnya sertifikasi halal bersifat voluntary (sukarela), dalam UUJPH menjadi mandatory (keharusan). Karena itu, semua produk yang masuk, beredar, dan diperdagangkan di wilayah Indonesia wajib bersertifikat halal. ${ }^{51} \mathrm{Hal}$ inilah yang menjadi pembeda utama dengan produk perundang-undangan sebelumnya yang lebih dahulu terbit. Nantinya sebagai penanggung jawab sistem jaminan halal dilakukan oleh pemerintah yang diselenggarakan Menteri dengan membentuk Badan Penyelenggara JPH (BPJPH) yang berkedudukan di bawah dan bertanggung jawab kepada Menteri. ${ }^{52}$ Apabila diperlukan BPJPH dapat membentuk perwakilan di daerah ${ }^{53}$.

\footnotetext{
${ }^{48}$ Lihat pasal 1 ayat (1) UUJPH.

${ }^{49}$ Pasal Pasal 1 ayat (3) UUJPH.

${ }^{50}$ Lihat penjelasan UUJPH

${ }^{51}$ Pasal 4 UUJPH

52 Sebagai tindak lanjut dari UUJPH Presiden Joko Widodo mengeluarkan Peraturan Presiden (Perpres) No. 83 Tahun 2015 tentang Kementerian Agama di dalamnya menegaskan kedudukan Badan Penyelenggara Jaminan Produk Halal (BPJPH) yang mempunyai tugas melaksanakan penyelenggaraan jaminan produk halal sesuai dengan ketentuan peraturan perundang-undangan yang kedudukannya setingkat dengan Direktorat Jenderal.

${ }^{53}$ Pasal 5 UUJPH
} 
BPJPH memiliki kewenangan sebagai berikut: ${ }^{54}(1)$ merumuskan dan menetapkan kebijakan JPH; (2) menetapkan norma, standar, prosedur, dan kriteria JPH; (3) menerbitkan dan mencabut Sertifikat Halal dan Label Halal pada Produk; (4) melakukan registrasi Sertifikat Halal pada Produk luar negeri; (5) melakukan sosialisasi, edukasi, dan publikasi Produk Halal; (6) melakukan akreditasi terhadap LPH (lembaga penjamin halal); (7) melakukan registrasi Auditor Halal; (8) melakukan pengawasan terhadap JPH; (9) melakukan pembinaan Auditor Halal; dan (10) melakukan kerja sama dengan lembaga dalam dan luar negeri di bidang penyelenggaraan JPH.

Dalam melaksanakan wewenangnya BPJPH bekerja sama dengan Kementerian dan/atau lembaga terkait, Lembaga Pemeriksa Halal (LPH); dan Majelis Ulama Indonesia (MUI). Kerja sama BPJPH dengan LPH dilakukan untuk pemeriksaan dan/atau pengujian Produk. Kerja sama BPJPH dengan MUI dilakukan dalam bentuk sertifikasi Auditor Halal, penetapan kehalalan produk, akreditasi LPH. ${ }^{55}$

Untuk menjamin kelancaran proses produksi halal pelaku usaha berhak memperoleh beberapa hal yaitu informasi, edukasi, dan sosialisasi mengenai sistem JPH; pembinaan dalam memproduksi Produk Halal; dan pelayanan untuk mendapatkan Sertifikat Halal secara cepat, efisien, biaya terjangkau, dan tidak diskriminatif. Selain itu, pelaku usaha yang mengajukan permohonan Sertifikat Halal wajib ${ }^{56}$ : (1) memberikan informasi secara benar, jelas, dan jujur; (2) memisahkan lokasi, tempat dan alat penyembelihan, pengolahan, penyimpanan, pengemasan, pendistribusian, penjualan, dan penyajian antara Produk Halal dan tidak halal; (3) memiliki Penyelia Halal; dan (4) melaporkan perubahan komposisi Bahan kepada BPJPH.

Bagi Pelaku Usaha yang telah memperoleh sertifikat halal ada beberapa kewajiban yang harus dilakukan yaitu: (1) mencantumkan Label Halal terhadap Produk yang telah mendapat Sertifikat Halal; (2) menjaga kehalalan Produk yang telah memperoleh Sertifikat Halal; (3) memisahkan lokasi, tempat dan penyembelihan, alat pengolahan, penyimpanan, pengemasan, pendistribusian, penjualan, dan penyajian antara Produk Halal dan tidak halal; (4) memperbarui Sertifikat Halal jika masa berlaku Sertifikat Halal berakhir; dan (5) melaporkan perubahan komposisi Bahan kepada BPJPH.

\footnotetext{
${ }^{54}$ Pasal 6 UUJPH

${ }^{55}$ Pasal 10 UUJPH

${ }^{56}$ Pasal 24 UUJPH
}

Terhadap pelaku usaha yang memproduksi produk dari bahan yang berasal dari bahan yang diharamkan dikecualikan dari mengajukan permohonan Sertifikat Halal. Pelaku Usaha semacam ini wajib mencantumkan keterangan tidak halal pada produk..$^{57}$ Pengaturan semacam itu sangat penting mengingat penduduk Indonesia terdiri dari masyarakat yang memiliki kepercayaan, agama dan keyakinan yang begitu plural. Oleh karena itu, terhadap produk atau makanan yang berasal dari daging babi, anjing dan hewan lainnya yang dinyatakan tidak halal untuk golongan masyarakat tertentu tidak adanya label maupun sertifikat halal pun tidak menghalangi mereka untuk memakan produk tersebut. ${ }^{58}$

Tata cara memperoleh Sertifikat Halal ${ }^{59}$ diawali dengan pengajuan permohonan Sertifikat Halal oleh Pelaku Usaha kepada BPJPH. Selanjutnya, BPJPH melakukan pemeriksaan kelengkapan dokumen. Pemeriksaan dan/ atau pengujian kehalalan Produk dilakukan oleh LPH. $\mathrm{LPH}$ tersebut harus memperoleh akreditasi dari BPJH yang berkerja sama dengan MUI. Penetapan kehalalan Produk dilakukan oleh MUI melalui sidang fatwa halal MUI dalam bentuk keputusan Penetapan Halal Produk yang ditandatangani oleh MUI. BPJPH menerbitkan Sertifikat Halal berdasarkan keputusan Penetapan Halal Produk dari MUI tersebut. Sertifikat Halal berlaku selama 4 (empat) tahun sejak diterbitkan oleh BPJPH, kecuali terdapat perubahan komposisi Bahan. Sertifikat Halal wajib diperpanjang oleh Pelaku Usaha dengan mengajukan pembaruan Sertifikat Halal paling lambat 3 (tiga) bulan sebelum masa berlaku Sertifikat Halal berakhir.

Terkait biaya, sertifikasi halal dibebankan kepada pelaku usaha yang mengajukan permohonan Sertifikat Halal. Dalam rangka memperlancar pelaksanaan penyelenggaraan JPH, Undang-Undang ini memberikan peran bagi pihak lain seperti Pemerintah melalui anggaran pendapatan dan belanja negara, pemerintah daerah melalui anggaran pendapatan dan belanja daerah, perusahaan, lembaga sosial, lembaga keagamaan, asosiasi, dan komunitas untuk memfasilitasi biaya sertifikasi halal bagi pelaku usaha mikro dan kecil.

\footnotetext{
${ }^{57}$ Pasal 26 UUJPH

58 Persoalan semacam ini pernah mencuat dan dipersoalkan sebagaimana tertuang dalam Putusan Mahkamah Konstitusi Nomor 2/PUU-IX /2011.

${ }^{59}$ Pasal 29-39 UUJPH
} 


\section{Sertifikasi pada Pangan Non Halal}

Berlakunya UUJPH yang disahkan DPR pada 24 September 2014 mengharuskan produsen yang menyatakan produknya sebagai produk halal wajib mencantumkan sertifikasi halal dari otoritas dalam hal ini Badan Penyelenggara Jaminan Produk Halal (BPJPH), sertifikasi bukan lagi urusan sukarela (voluntary) melainkan merupakan kewajiban (mandatory), peraturan ini nantinya juga berlaku pada produk-produk impor.

Pengaturan sertifkasi produk halal sebetulnya bukan hanya diatur dalam UUJPH melainkan banyak tersebar dalam pelbagai perundang-undangan dan peraturan turun di bawahnya maupun keputusan lembaga negara, salah satunya dapat ditelusuri pada Putusan Mahkamah Konstitusi Nomor $2 /$ PUU-IX/2011 yang merupakan respon dari permohonan uji materi (judicial review) atas Pasal 58 ayat 4 Undang-Undang Nomor 18 Tahun 2009 tentang Peternakan dan Kesehatan Hewan (UU$\mathrm{PKH})^{60}$ yang menyatakan:

Produk hewan yang diproduksi di dan/atau dimasukkan ke wilayah Negara Kesatuan Republik Indonesia untuk diedarkan wajib disertai sertifikat veteriner dan sertifikat halal.

Norma tersebut dalam arti lain dapat mengandung makna produk hewan yang diproduksi di dan/atau dimasukkan ke wilayah Negara Kesatuan Republik Indonesia yang bertujuan untuk diedarkan tidak boleh tidak harus disertai pernyataan dari pihak berwenang mengenai penyakit hewan (veteriner) dan pernyataan halal. ${ }^{61}$

Mahkamah sependapat dengan para Pemohon yang merupakan pedagang daging babi, daging anjing dan peternak babi yang dagangannya tidak memerlukan sertifikat halal, sehingga secara fakta bidang usaha mereka merupakan atau berhubungan dengan hewan atau produk hewan yang tidak halal. Oleh karena itu, kalau kewajiban adanya selain sertifikat veteriner, juga sertifikat halal sebagaimana yang ditentukan, tidak mungkin produk hewan tersebut mendapat sertifikat halal, ini sama dengan sikap Pemerintah yang tidak mensyaratkan sertifikat halal bagi produk hewan

${ }^{60}$ UU No. 18 Tahun 2009 tentang Peternakan dan Kesehatan Hewan kemudian direvisi melalui UU No. 41 Tahun 2014 tentang Perubahan Atas UU No. 18 tahun 2009 tentang Peternakan dan Kesehatan Hewan

${ }^{61}$ Dalam bagian Penjelasan Pasal 58 ayat (4) UUPKH yang dimaksud dengan "Sertifikat Veteriner" adalah surat keterangan yang dikeluarkan oleh dokter hewan berwenang yang menyatakan bahwa produk hewan telah memenuhi persyaratan keamanan, kesehatan, dan keutuhan. Sedangkan yang dimaksud dengan "Sertifikat Halal" adalah surat keterangan yang dikeluarkan oleh lembaga penjamin produk halal di negara kesatuan Republik Indonesia. yang memang tidak halal, sudah diatur antara lain dalam Peraturan Menteri Pertanian Nomor 381/Kpts/ OT.140/10/2005 tentang Pedoman Sertifikasi Kontrol Veteriner Unit Usaha Pangan Asal Hewan. Peraturan tersebut tidak mewajibkan syarat halal bagi pangan asal babi. Demikian pula tidaklah mungkin Lembaga Pengkajian dan Pengawasan Obat dan Makanan dan Majelis Ulama Indonesia (LPOM-MUI) sebagai institusi yang berwenang memberikan sertifikat halal, memberikan sertifikat halal dimaksud.

Produk hewan yang berasal dari hewan lain, bagi golongan masyarakat tertentu, yang mempercayai hewan tersebut sebagai hewan yang suci atau hewan yang dilarang untuk dikonsumsi, maka meskipun untuk produk hewan yang berasal dari hewan lain tersebut telah mendapat sertifikat veteriner maupun sertifikat halal pastilah tidak berlaku bagi mereka yang menganut kepercayaan demikian. Mengenai produk hewan yang berasal dari babi meskipun telah memperoleh sertifikat veteriner tanpa mendapat sertifikat halal, bagi golongan masyarakat tertentu yang memang membolehkan untuk mengonsumsinya tidak adanya sertifikat halal tidak menghalangi mereka untuk mengonsumsinya;

Mahkamah selanjutnya menguraikan, Pasal 58 ayat (4) UU 18/2009 bertentangan dengan UUD 1945 sepanjang tidak dimaknai bagi produk hewan yang memang tidak halal, tidak disyaratkan adanya sertifikat halal dan memutuskan Pasal 58 ayat (4) UUPKH bertentangan dengan Undang-Undang Dasar Negara Republik Indonesia Tahun 1945 sepanjang frasa “...wajib disertai sertifikat veteriner dan sertifikat halal' dimaknai mewajibkan sertifikat halal bagi produk hewan yang memang tidak dihalalkan dan tidak mempunyai kekuatan hukum mengikat sepanjang frasa "... wajib disertai sertifikat veteriner dan sertifikat halal' dimaknai mewajibkan sertifikat halal bagi produk hewan yang memang tidak dihalalkan. Dengan putusan ini, para pedagang babi dan anjing tidak wajib mencantumkan sertifikat halal dalam produk dagangan karena memang bagi umat muslim daging hewan tersebut tidak halal.

\section{Penutup}

Sertifikasi halal pada produk pangan sesungguhnya memiliki fungsi dan peran yang sangat menentukan bukan saja dari sisi konsumen (masyarakat) tetapi juga dari perspektif pelaku usaha. Konsumen membutuhkan produk pangan aman dikonsumsi, bebas penyakit, 
bergizi dan sehat serta mendatangkan ketentraman secara batin yang tidak tercampur dengan bahan-bahan non halal. Dari sisi pelaku usaha mereka membutuhkan konsumen yang loyal sebagai target pemasaran produk yang mereka hasilkan. Terlebih pada saat ini pangan halal bukan saja dibutuhkan bagi masyarakat muslim, tetapi sudah menjadi keperluan mendesak bagi masyarakat non muslim. Hal ini dibuktikan secara faktual dengan maraknya tren halal yang tengah menggejala di negaranegara yang justru berpenduduk mayoritas non muslim. Fenomena ini dapat dimaklumi karena secara science pangan yang dinyatakan halal sudah barang tentu aman dan menyehatkan, kesadaran masyarakat dunia akan pentingnya pangan halal juga mulai meningkat. Hal ini tentu menggembirakan dan harus didukung dengan iklim usaha yang kondusif dengan mendorong terbitnya regulasi dan kebijakan yang berpihak kepada konsumen dan pelaku usaha sehingga ada jaminan kepastian hukum.

Dari segi timing, lahirnya Undang-undang Jaminan Produk Halal (UUJPH) sesungguhnya terbilang sangat terlambat bila dibandingkan dengan negara tetangga seperti Malaysia dan Singapura yang telah melangkah begitu jauh dalam merespon kebutuhan pangan halal. Kedua negara ini bahkan telah memiliki pelabuhan halal yang menjadi pintu masuk bagi ekspor barang ke negara-negara Timur Tengah atau negara yang mensyaratkan produk yang diimpor harus bersertifikat halal. Sebagai negara yang berpenduduk mayoritas muslim terbesar di dunia sudah semestinya Indonesia bisa mengejar ketertinggalan tersebut sehingga tidak hanya dijadikan objek pemasaran produk yang berasal dari negara-negara lain. Hal ini bisa dimulai dengan mendorong terbitnya kebijakan halal yang progresif.[]

\section{Pustaka Acuan}

Amin, Ma'ruf, Fatwa Produk Halal, Melindungi dan Menentramkan, Jakarta: Pustaka Jurnal Halal, 2010. Fatwa dalam Sistem Hukum Islam, Jakarta: Elsas, 2011.

Era Baru Ekonomi Islam Indonesia, dari Fikih ke Praktik Ekonomi Islami, Jakarta: Elsas, 2011.

Abadi, Tulus Dkk, Tim Pengkajian Hukum tentang Peran Serta Masyarakat dalam pemberian Informasi Halal, Kementerian Hukum dan Hak Asasi Manusia Badan Pembinaan Hukum Nasional, Jakarta: 2011.

Basyir, Ahmad Azhar, Asas-Asas Hukum Muamalat (Hukum Perdata Islam), Yogyakarta: UII Press, 2009.
Chandrawulan, An An, Hukum Perusahaan Multinasional, Bandung: CV Kenimedia, 2014.

Hasan, Sofyan, Sertifikasi Halal dalam Hukum Positif, Regulasi dan Implementasinya di Indonesia, Yogyakarta: Aswaja Pressindo, 2014.

Hata, Perdagangan Internasional dalam Sistem GATT dan WTO, Aspek-Aspek Hukum dan Non-Hukum, Bandung: PT Refika Aditama, 2006.

Jazuni, Legislasi Hukum Islam di Indonesia, Bandung: PT Citra Aditya Bhakti, 2005

Majelis Ulama Indonesia, Himpunan Fatwa MUI Sejak 1975, Jakarta: PT Erlangga, 2015.

Masudi, Masdar Farid, Syarah Konstitusi UUD 1945 dalam Perspektif Islam, Jakarta: Puastaka Alvabet, 2010.

MD, Moh. Mahfud, Politik Hukum di Indonesia, Jakarta: PT Raja Grafindo Persada, 2009.

Miru, Ahmad, Prinsip-Prinsip Perlindungan Hukum Bagi Konsumen di Indonesia, Jakarta: PT Raja Grafindo Persada, t.t..

Naskah Akademik Rancangan Undang-Undang Jaminan Produk Halal.

Peraturan Pemerintah Nomor 69 Tahun 1999 Tentang Label dan Iklan Pangan

Nirwanda, Sapta, "Ikhtiar Menjadi Produsen Halal Lifestyle”, dalam GATRA, 19 Juli 2015.

Nugroho, Susanti Adi, Proses Penyelesaian Sengketa Konsumen Ditinjau dari Hukum Acara Serta Kendala Implementasinya, Jakarta: PT Prenada Media Group, t.t..

Sholeh, Asrorun Ni'am, "Halal Jadi Tren Global", dalam GATRA, 29 Juli 2015.

Sidabalok, Janus, Hukum Perlindungan Konsumen di Indonesia, Bandung: PT Citra Aditya Bakti, 2010.

Sofie, Yusuf, Kapita Selekta Hukum Perlindungan Konsumen di Indonesia, Bandung : PT Citra Aditya Bhakti, 2008.

Sumatupang, Violetta, Hukum Kepariwisataan Berbasis Ekspresi Budaya Tradisional, Bandung: Alumni, 2015.

Suntana, Ija, Politik Hukum Islam, Bandung: CV Pustaka Setia, 2014

Undang-Undang No. 8 Tahun 1999 tentang Perlindungan Konsumen.

Undang-Undang No. 36 Tahun 2009 tentang Kesehatan.

Undang-Undang No. 18 Tahun 2012 tentang Pangan. 
Wijatno, Serian dan Ariawan Gunadi, Perdagangan Bebas dalam Perspektif Hukum Perdagangan Internasional, Jakarta: Grasindo, 2014.

Yafie, Ali, Fikih Perdagangan Bebas, Jakarta: Teraju, 2004.
Laman:

Republika.co.id, "PDS Tolak RUU Jaminan Produk Halal", dalam http://www.republika.co.id/berita/ shortlink/31828, diunduh pada 22 Agustus 2015.

UU Jaminan Produk Halal Memberikan Kepastian Hukum Kepada Kosumen, sebagaimana dalam http://www. hukumonline.com/berita/baca/lt54241d9c5a5ed/uujaminan-produk-halal-berikan-kepastian-hukum-bagikonsumen, diunduh pada 22 Agustus 2015. 